\title{
Issues Impacting Sustainability in the Oil and Gas Industry
}

\author{
Mohamad Danish Anis ${ }^{1} \&$ Tauseef Zia Siddiqui ${ }^{2}$ \\ ${ }^{1}$ School of Mechanical, Aerospace \& Civil Engineering, University of Manchester, United Kingdom \\ ${ }^{2}$ Sustainability Specialist, SABIC, Jubail Industrial City, Saudi Arabia \\ Correspondence: Mohamad Danish Anis, School of Mechanical, Aerospace \& Civil Engineering, University of \\ Manchester, Greater Manchester, M13 0JQ, United Kingdom. Tel: 44-740-546-5936. E-mail: \\ danishanis10@hotmail.com
}

Received: August 24, 2015

Accepted: October 14, 2015 Online Published: November 30, 2015

doi:10.5539/jms.v5n4p115

URL: http://dx.doi.org/10.5539/jms.v5n4p115

\begin{abstract}
This research paper explores the concept of sustainability and the role played by O\&G industry in achieving sustainable development. The authors bring a rational approach in defining the key issues for the O\&G sector that affect sustainability as well as try to devise the inherent risks as well as mitigation approaches adopted by these companies. Sustainability is a topic gaining fast repute today. As new conventional oil and gas sources decline, unconventional sources, including shale gas in the US, oil sands in Canada, coal seam gas in Australia, and deep-water offshore wells in Brazil, West Africa and Asia have been identified as key areas with significant reserves potential. Despite the growth potential, sustainability risks such as climate change, safety risks, and community disagreements exert pressure on the economic feasibility of these opportunities.

The three components of sustainable development: economic, environmental and social, often referred to as the 'Triple Bottom Line' or TBL, can be used in evaluating a company's performance in financial, environmental and social dimensions. These three dimensions of sustainable development, as explained by John Elkington and adopted by Shell's first sustainability report in 1997, are also commonly referred to as the 3Ps: People, Planet and Profit.

The paper also focuses on analyzing the various threats that could obstruct sustainable development being carried out by companies in the oil and gas industry. The importance of sustainable economic growth with regards to the oil and gas industry has also been highlighted. The 3Ps explained above can be used to categorize the key issues/risks that impact sustainability. The researchers concluded that the sustainability programs followed by oil and gas industry are not satisfactory; however there is strong evidence of improvement in near future. Towards the end, the researchers have tried to list the Strategies and Methodologies for enhancing the effectiveness of sustainability strategies and programs for the sector.
\end{abstract}

Keywords: sustainability, sustainable development, O\&G Sector, Triple Bottom Line, climatic change, 3Ps

\section{Introduction}

Issues relating to global health and sustainability must stay high on the agenda if we are to cope with an aging and ever-increasing population, with growing pressure on resources and with rising global temperatures. The risks and dangers need to be assessed and then confronted.

-Martin Rees

Around two decades have passed since the Earth Summit of 1992 was held in Rio de Janeiro where the countries adopted 'Agenda 21' i.e. a proposal to ensure social equity, boost economic growth and ensure environmental protection (UNSD, 1992). This was also the first time when the lifestyle of the current civilization was assessed and the need for change in the production and consumption pattern was proposed. The same was followed by United Nations Framework Convention on Climate Change (UNFCCC) in 1994. Adopted at Rio Convention, UNFCCC aspired to prevent the dangerous human interference with the climate. The ultimate objective of the convention was to stabilize green house gas concentrations and prevent hazardous human induced climate change (to be achieved within a time frame sufficient to allow ecosystems to adapt naturally), to ensure food production is not threatened and enable sustainable economic development. Moreover, the O\&G sector is the most vital industry to the world's economy and has an essential contribution in providing energy for the society's 
development. In the wake of the rise in unconventional gases and the Gulf of Mexico disaster, sustainability has become the need of the hour. It is for the same reason that organizations like IPIECA, API and OGP recognize the importance of managing sustainability in the energy sector and encourage their member companies to communicate with their stakeholders - the economic, environmental, governance and social impacts of their businesses in the form of 'Voluntary Sustainability Reports' for the sake of transparency and disaster management.

As new conventional oil and gas sources decline, unconventional sources, including shale gas in the US, oil sands in Canada, coal seam gas in Australia, and deep-water offshore wells in Brazil, West Africa and Asia have been identified as key areas with significant reserves potential. Despite the growth potential, sustainability risks such as climate change, safety risks, and community disagreements exert pressure on the economic feasibility of these opportunities.

\section{Rationale for Doing Research Work on the Topic}

While offshore technology has made developments in exploring and drilling deep water O\&G, they have also become the sources of environmental pollution and hazardous mishaps at various stages of the production process. Drilling accidents that are caused due to equipment failure, personnel mistakes or an extreme natural calamity can be associated to large scale hydrocarbon leakage and oil spills. On occasions of such prolonged hydrocarbon gushing, the reason for system failure is usually when the extremely high drilling zone pressure cannot be overcome by well muffling process. Alternatively, on regular or routine hydrocarbon blowouts during drilling operations, counter measures can be taken such as blowout preventers or changing density of drilling fluid. However, the fact remains that any kind of leakage can prove to be catastrophic.

There is a coherent relationship established between major O\&G mishaps and lack of sustainable practices. The previous three decades have seen numerous terrible offshore disasters. One such incident that left about 167 dead was the Piper Alpha - Oil Rig Fire in 1988. A similar gas leak exploded the Amuay Oil Refinery in Venezuela killing 39. On another occasion, an oil spill in the Gulf of Mexico in 2010 was followed by the explosion and sinking of Deepwater Horizon Oil rig (Castagra.org, 2015). In the light of such disasters in O\&G industry, it becomes imperative for the oil and gas exploring companies to follow the sustainability guidelines.

A simple perception of sustainability is conserving the natural environment for resources that directly or indirectly impact our survival and the environmental, economic and social well-being of a community. As mentioned earlier, this is where the voluntary sustainability reports help both internal and external stakeholders to keep a track of the environmental and social impacts of O\&G production businesses by adding value and suggesting improvements to avoid such disasters in future.

\subsection{How Sustainability Drives Economic Development?}

Going by its definition, sustainable development explores relationship among economic development, environmental quality and social equity. The economic dimension of sustainable development is referred to as profit. However, economic development cannot just be summarized by the materialistic gains made. The development has to be socially inclusive and environmentally sustainable. When the companies involved create an economic value to their working environment, we term it as sustainable growth. The real purpose of sustainable growth in the industrial context is when the 'Real Output', measured by GDP-Gross Domestic Product, increases over time at constant prices. It is also necessary that sustainable economic growth doesn't create economic problems by exhausting resources for future generations.

It is imminent that with rising population in a particular region or with the industrialization of a fertile land, there is an overall rise in aggregate demand due to consumer spending. Therefore, the role of sustainable economic development shouldn't be limited to creating value. A sustained growth is an overall increase in output. Failure to increase the output would invariably result in a rise of prices for the present and future generations (Islam \& Sumathy, 2013).

A major role of the multinational companies involved in oil exploration is generating revenue. The statistics in Figure-1 show the annual revenue in billion US Dollars of three leading O\&G companies of the world over the past few years. 


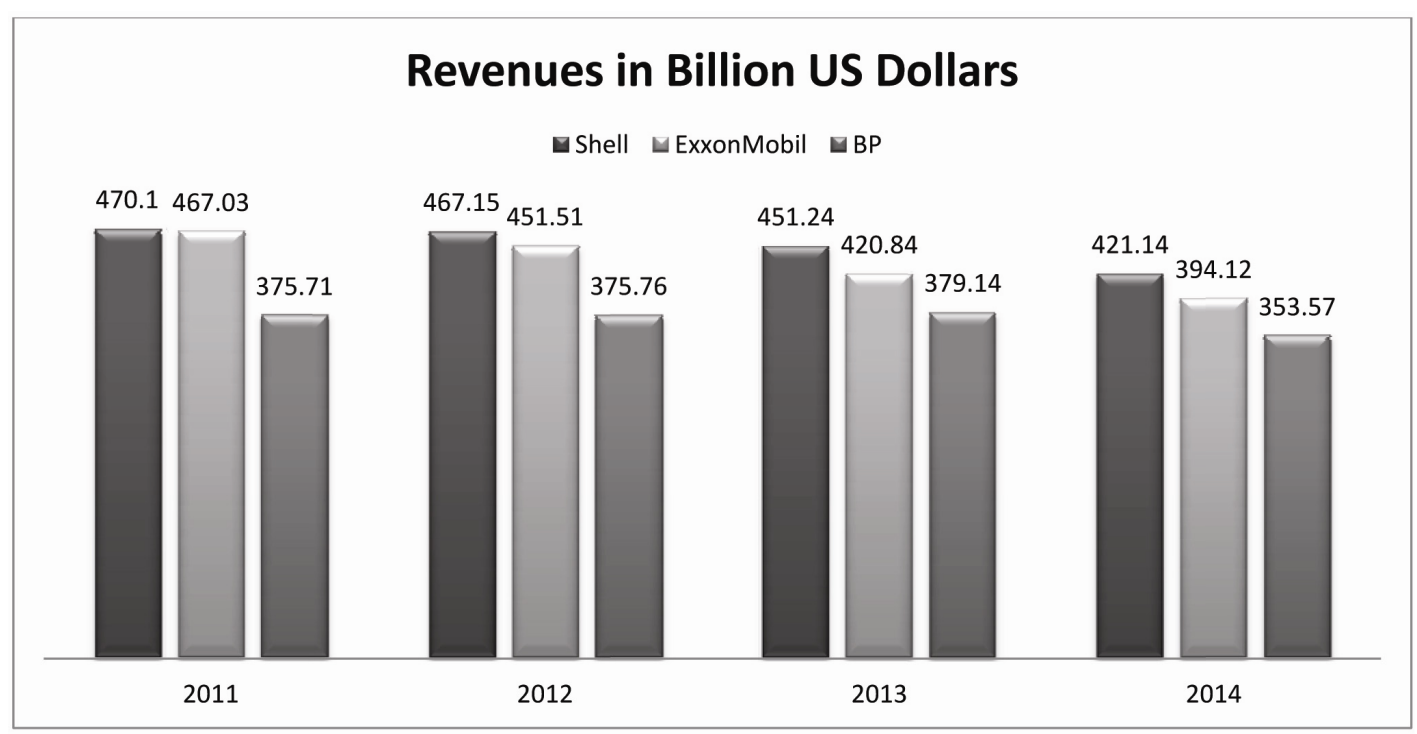

Figure 1. Annual revenues of Shell, ExxonMobil and BP in \$ billions

Compiled from: Statista, 2015.

A close scrutiny to the figures reveals that the revenues generated by these oil and gas companies individually outweigh the GDP of the countries which, according to the IMF (International Monetary Fund), have shown the fastest GDP growth in the previous decade, namely Qatar, Libya, Azerbaijan and Equatorial Guinea (Aridas \& Pasquali, 2013). China is the world's most populous country with the fastest growing economy. The IMF indicates that annual GDP growth rate in China has risen to $10 \%$ in just three decades and going by 'The Rule of 70 ', this economy would double itself in the next seven years. It shouldn't come as a surprise that China is the fourth largest oil producer in the world, reassuring the fact that the oil and gas industry drives economies of countries.

Oil exploration today is also used in producing electricity. Oil power stations convert the chemical energy generated by combusting oil into electrical energy that can be used at consumer homes and businesses. For a country as large as the United States, nearly $40 \%$ of the nation's entire power needs are satisfied through oil being used as a fuel (Powerscorecard.org, 2015). Although oil has predominantly been used for transportation and home heating purposes, the increasing usage of oil as a fuel to produce electricity in power plants has lead to a significant increase in worldwide fuel consumption and subsequently having harmful environmental effects.

The lesson to be learned from sustainable economic growth is that the $1^{\text {st }}$ pillar of sustainable development, the economic wellbeing, is something achievable. It is being achieved in many parts of the planet and oil companies play a vital role in it. The business investments of oil companies indirectly facilitate population growth. With rising population comes better health facilities and medical care. Subsequently, the average life expectancy has increased. Infant mortality rates have declined from 134 per 1000 to just 37 per 1000 live births. Economic development can improve lives where people get the confidence that their children would grow up healthy.

In the race for gaining access to $O \& G$ reserves, companies are bringing previously considered unconventional plays such as shale gas, coal seam gas, oil sands and deep-water wells to the center of their strategies. Despite the growth potential, the unconventional sources raise a number of environmental and social hurdles such as spills, safety risks, large greenhouse gas (GHG) emissions, losses of natural resources, and land \& water degradation (UK Environmental Agency, 2013). In addition, many of the new sources are found in nontraditional regions, where companies must overcome local barriers to entry that can range from bribery to opposition by community groups to war.

Furthermore, as these unconventional sources are increasingly tapped, poor management of risks by some companies is prompting an increase in regulations. For instance, after the occurrence of BP's Macondo disaster, the US placed a temporary moratorium on offshore exploration and well development (Steffy, 2010). The US government, after having lifted the ban, now says that operations must meet higher standards. The spill has prompted other countries, such as Brazil, to review their offshore permitting. Despite having a more cautionary approach, permits are still being granted. 
Also, oil sands are facing regulatory fights posing operational threats such as construction delays and the possible cancelation of the Keystone XL pipeline, intended to transport Alberta's bitumen to Gulf Coast refineries. Furthermore, natural gas opportunities are also facing legal challenges such as either banning or placing moratoriums on hydraulic fracturing in various parts of the world, including United Kingdom (Scotland), US, Germany and France (Farahani et al., 2015). The US Environmental Protection Agency (EPA) is also assessing stronger federal oversight on shale gas production. Also, coal seam gas in Australia faces increasing scrutiny from regulators, impacting its growth. These developments interfere with companies' abilities to capitalize on raising demand, which may be significant. Specifically, according to the US Energy Information Administration, natural gas consumption is expected to increase by $44 \%$ by 2035 from 2007 (US Energy Information Administration, 2015). Also, the combustion of natural gas emits about 30\% less GHG emissions than oil per energy basis, prompting speculations that natural gas will increasingly be used in carbon-constrained markets.

\section{Research Methodology}

Research methodology is an amalgamation of research approach and research paradigm that describes or illustrates the strategy that could be adapted by the researchers and scholars while conducting research (DeMarrais and Lapan, 2004). Research paradigm or the method of research is grouped into two types namely positivism (objectivity) and hermeneutics (subjectivity) (DeMarrais \& Lapan, 2004). This research paper makes use of both positivism and hermeneutics.

The research approaches also are of two types- quantitative as well as qualitative (Shank, 2002). This paper utilizes quantitative research to find the association of a dependent variable like risks associated in the practice of O\&G extraction with another independent variable like the concept of Sustainability. This study poses questions to the ongoing sustainable measures being observed in the O\&G industry and analysis the answers to those questions. This approach is known to gather proofs and evidences and find some information that was not determined or resulted previously (Patton, 2001).

This paper also follows a qualitative research approach as all the secondary data has been collected by the authors. The secondary data here highlights the risks to sustainability and has been collected from various sources like the annual sustainability reports of the Oil and Gas companies, Dow Jones sustainability and Sustainability award documents. In addition to that, the identified sustainable models have been studied and were found to be addressing various environmental issues. An attempt has been made to highlight the ongoing efforts for the conservation/restoration of the natural habitat of flora and fauna and improving their neighborhoods. All these efforts bring in a sense of reverence to nature, water conservation, energy conservation and community service with regards to environment, and waste management. The paper also highlights certain efforts made at reducing individual consumptive patterns, essentially the practice of the $3 \mathrm{R}$ 's- reduce, reuse and recycle in the O\&G industry.

\section{Risks to Sustainability in the Oil and Gas Industry}

The earth's population today has reached 7.2 billion and there would be added another billion to this in the next two decades. With these billions of people working their way towards economic improvement, we have the world economy growing rapidly, yet in a remarkably unequal fashion. This is threatening the planet itself. Humanity depends on natural provisions like food, water, survival materials, safety from environmental threats and diseases. Yet for a species dependant on the beneficence of environmental services, the job done to protect physical environment doesn't suffice (Sharma \& Aggarwal, 2014). Thus, the growing economies have started to cause environmental crises, jeopardizing the safety of all other species. Large scale economic activities are changing Earth's climate, water cycle and even the ocean chemistry.

Practicing sustainable development would do well to ensure that the growing economies are being well spread across the land. But the unprecedented risks to sustainability are felt by the rich and poor alike. The risks to sustainability can be broadly categorized into two types-Operational and Geographic risks.

\subsection{Operational Risk}

These are defined as the risk of loss resulting from inadequate or failed processes, people and systems or from external events. This may include legal risk, but excludes strategic and reputational risk. In the context of Oil and Gas, the risks are highly dependent on the nature of the industry. It includes the following

Carbon Emission: Oil \& Gas companies have high GHG emissions intensity compared to other sectors. O\&G production involves the venting, flaring, and accidental release of methane (natural gas). Both Tollefson (2013) and Pawan (2014) have argued that methane is a GHG with 25 times more global warming potential than $\mathrm{CO}_{2}$. 
Drilling and production also involve extensive use of various engines and compressors that emit significant amounts of GHG. Despite having established GHG emission reduction regulations in the EU and associated policies in Japan, overarching regulations are largely stalled in major economies, such as the US and Canada. Nevertheless, in the long run, the pressure to reduce emissions on one of the most GHG-intensive industries remains high. Our carbon emission analysis ranks companies according to their specific exposure to existing or upcoming regulations while accounting for the carbon intensity of the industry. We also consider the carbon intensity of each company's activities (e.g., conventional O\&G vs. oil sands), companies' competitive positioning in the natural gas market, and overall carbon emission reduction management and performance.

Within carbon emissions as a key issue, we analyze the operational GHG emissions' risk exposure, risk management and historical performance trends:

\begin{tabular}{|ll|ll|}
\hline \multicolumn{2}{|c|}{ Risk Exposure } & \multicolumn{2}{c|}{ Risk Management } \\
\hline$\checkmark$ & Sector-Specific profile for Carbon Emissions & $\checkmark$ & Carbon Mitigation Strategy \\
\hline$\checkmark$ & Carbon Regulations related risk & $\checkmark$ & Policies and implementation mechanisms (carbon \\
& & $\begin{array}{l}\text { capture and sequestration, energy efficiency, } \\
\text { renewable energy technologies) }\end{array}$ \\
\hline & $\checkmark$ & Carbon Intensity Reserves \\
\hline & $\checkmark$ & Flaring Reduction \\
\hline & $\checkmark$ & Improvement Targets \\
\hline & $\checkmark$ & Carbon Emissions Performance Indicators \\
\hline
\end{tabular}

Land use pattern \& Biodiversity: Industries, NGOs and governments continue to quantify their value along with increased regulations. Cross-industry impacts such as damages to fisheries, lost tourism, or devaluation of property values have already affected the $O \& G$ industry. The effects on surrounding terrain may prompt traditional land users and owners to demand compensation. As natural resources and populations of threatened species decline as a consequence of poor land management and over consumption from a growing population, the costs to protect biodiversity or compensate for destruction will increasingly burden the industry.

Large oil spills are notorious for their devastating effects on wildlife (Prasad et al., 2014). Vivid images of oil spills and their impacts on natural habitats can tarnish the reputation of oil companies. Additionally, perceived systemic risks in the industry can create widespread public opposition to unconventional extraction practices such as hydraulic fracturing.

For the oil \& gas industry, a number of unconventional production methods, which were previously considered unfeasible, are increasingly being used by publicly traded companies to meet future energy and shareholder demands. Operations such as offshore \& ultra-deep wells, shale gas \& hydraulic fracturing, coal seam gas and oil sands bring with them an increasing of risk to biodiversity and land use.

To assess performance on this key, issue we address the following:

\begin{tabular}{|c|c|}
\hline Risk Exposure & Risk Management \\
\hline $\begin{array}{l}\checkmark \quad \text { Strengthening regulations for wildlife } \\
\text { conservation, biodiversity economic worth and } \\
\text { fragility in areas of companies' proven reserves. }\end{array}$ & $\begin{array}{l}\checkmark \quad \text { Company commitments and practices to } \\
\text { minimize disturbances }\end{array}$ \\
\hline \multirow{3}{*}{$\begin{array}{l}\checkmark \quad \text { Types of operations and their risks towards } \\
\text { biodiversity and land use. }\end{array}$} & $\checkmark \quad$ Land reclamation programs and performances \\
\hline & $\checkmark \quad$ Programs to minimize disturbance \\
\hline & $\begin{array}{l}\checkmark \text { Controversies related to adverse ecosystem or } \\
\text { community impacts. }\end{array}$ \\
\hline
\end{tabular}

Over the years, oil and gas developments on public lands have damaged the ecosystem and contaminated soil, air and water. The offshore structures and subsea systems used by companies for the exploration of oil are known to affect the marine life too. There are thousands of oil rigs and ships operating worldwide and with that number increasing rapidly, there has also been a corresponding increase in the number of oil spills. Even today, no one can exactly tell how many more years it would take for the Gulf of Mexico to heal from the deadly infusion of oil, methane and toxic dispersants post the catastrophic oil rig explosion in 2010. The environmental disaster that was to follow was the worst of its kind and serves as the perfect example of how the natural habitat of marine species has been threatened in regions that are vulnerable to oil spills. 
The Centre for Biological Diversity in the US has launched several campaigns and filed lawsuits to halt oil and gas development in US waters which are a vital habitat to critically endangered species. The Centre's protests are also against oil and gas leases worth millions of US dollars which in more than one ways compromise with the environment's safety against greenhouse gas emissions, degrade water quality and imperil endangered flora $\&$ fauna species (US Centre for Biological Diversity, 2015).

Health \& Safety: Both onshore and offshore operations have high probabilities of health and safety (H\&S) incidents that can have devastating consequences. The significant H\&S risks for the O\&G sector in general and E\&P industry in particular are embodied by devastating events such as BP's Deepwater Horizon offshore rig (Macondo well) explosion in 2010 leading to 11 fatalities. H\&S management in tandem with integrity of wells, rigs, pipelines and installations are instrumental in minimizing risk of well blowups, fires and mishaps that can lead to worker fatalities and injuries.

Safe and incident-free operations are also a key to strong productivity and efficiency. Furthermore, large disasters are not extremely common but they still require significant resources to build up prevention \& emergency response capacity. Failing to adequately manage such risks will result in not only worker injuries or deaths, but also regulatory and other legal penalties. For instance Anadarko, with $25 \%$ equity stake in the Macondo well, was in danger of facing liabilities as well as a class action federal lawsuit being filed against it for an alleged cover-up of safety issues. Even though the charges of negligence on Anadarko's part in drilling operations were overruled in 2014, the District Judge at the US Department of Justice still held Anadarko liable spill damages and penalties (Feeley \& Brubaker, 2014). Noble Energy and Apache have also had numerous fines and penalties related to $\mathrm{H} \& \mathrm{~S}$ violations.

We assess H\&S performance based on risk exposure evaluation, risk management and analysis of historical performance indicators.

\begin{tabular}{|c|c|}
\hline $\begin{array}{l}\text { Risk Exposure } \\
\text { This is evaluated for each company on the basis of the } \\
\text { following criteria: }\end{array}$ & $\begin{array}{l}\text { Risk Management } \\
\text { Assessed through the following metrics: }\end{array}$ \\
\hline $\begin{array}{l}\checkmark \quad \text { Standard local safety performance- broken down } \\
\text { by percentage of production in each country. }\end{array}$ & $\begin{array}{ll}\checkmark & \text { H\&S Governance and Strategy } \\
\text { - } & \text { Policies and standards of practice } \\
\text { - } & \text { H\&S management systems and certification } \\
\text { - } & \text { Improvement targets }\end{array}$ \\
\hline & $\begin{array}{l}\checkmark \quad \text { H\&S Performance Indicators: } \\
\text { - Total Reportable Injury Frequency Rate (TRI), } \\
\text { Lost Time Injury Frequency Rate (LTI) and fatality } \\
\text { rates. } \\
\text { - Evidence of safety-related incidents and } \\
\text { controversies. }\end{array}$ \\
\hline
\end{tabular}

Referring again to the catastrophic Gulf of Mexico accident; the oil rig explosion claimed lives of 11 workers and severely injured many others. It has been quiet dramatically demonstrated how offshore oil rig activities entail the hazard of a major mishap with hazardous consequences threatening the life \& health of workers; pollute environment and cause economic and energy losses. However, it is not just the rig explosion and the outbreak of fire which cause the majority of injuries to the workers. Latest statistics from UK's Hazardous Installations Directorate Offshore Division (OSD) show that a lot of serious injuries are sustained by the workers due to the work process environment also. 


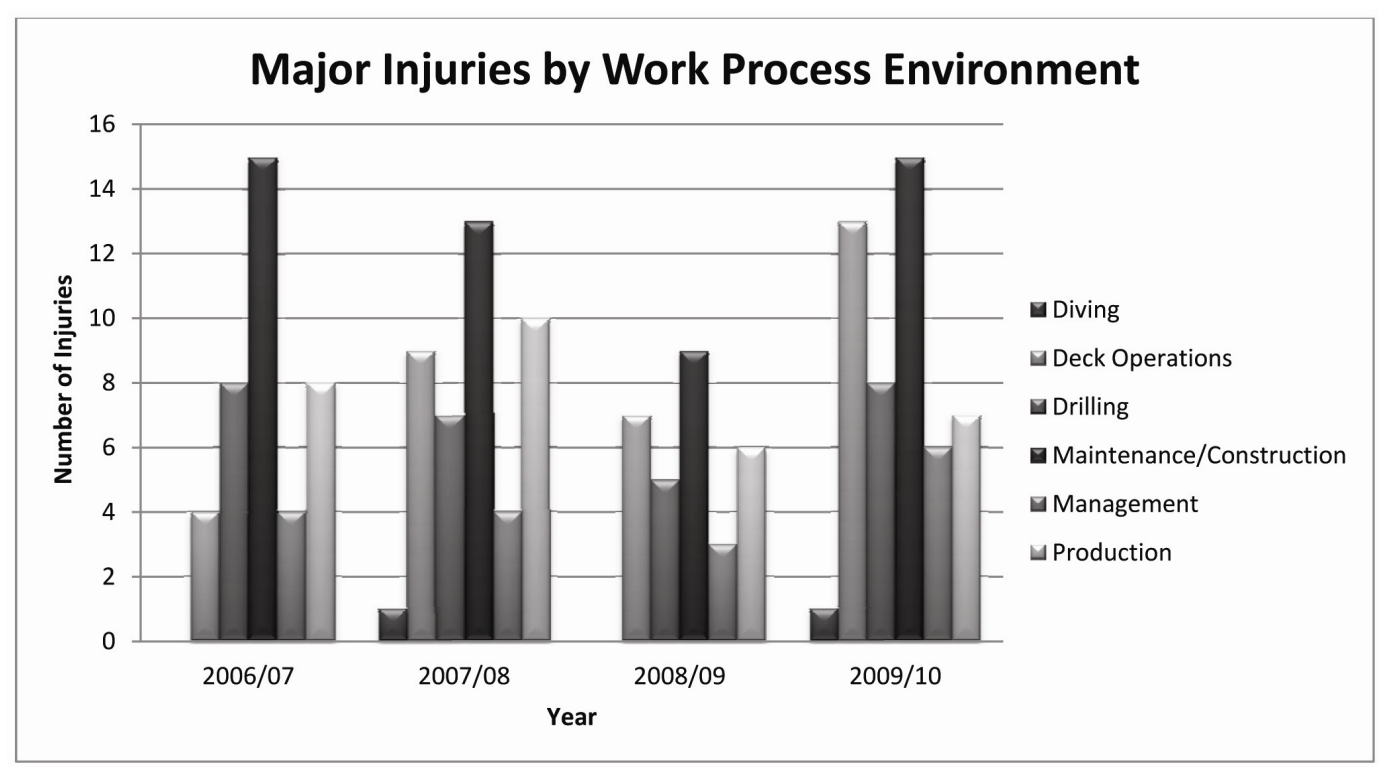

Figure 2. Injuries due to work process environment

Source: Health and Safety Executive, 2010.

The graphic representation above show the number and nature of reported injuries by work process environment by a survey done over a period of four years. Maintenance/Construction and Deck Operations (which includes air and sea transport) injuries have dominated with a staggering $52.1 \%$ amongst all other major injuries.

\subsection{Geographical Risks}

In context to the oil and gas industry, geographical risks have very little to do with the landscape, region or earth bodies suitable for oil exploration. Instead, this section would mainly analyze the imminent corruption which sticks its head out in the industry. The government of a region that allows the flow of investments from foreign companies plays a vital role in the country's economic well being. However, when there is discrimination and ambiguity on the government's part, sustainable development no longer becomes a shared goal. Geographical risks, thus, play an important role in promoting unprecedented poverty, massive divisions and environmental stress.

Corruption in Oil and Gas Industry: The search for oil sources often leads to operations in regions characterized by political instability, violence, and corrupt business practices. Although such regions often offer strong opportunities for growth, the company stock prices can quickly devalue when investors become uncomfortable with regional political instability as turbulent situations can spill over and disrupt operations. Moreover, political regimes could demand payouts that would be illegal in many companies' home countries. Fines for violating these laws are also becoming greater and more common as countries such as the US or the UK increase requirements and enforcement of these laws.

To assess performance on this key issue we address the following:

\begin{tabular}{|l|ll|}
\hline \multicolumn{1}{|c|}{ Risk Exposure } & \multicolumn{1}{c|}{ Risk Management } \\
\hline $\begin{array}{l}\checkmark \quad \text { The perception of corruption in the countries of } \\
\text { operation is based on Transparency International's } \\
\text { Corruption Perception Index (CPI). }\end{array}$ & $\checkmark$ & Company commitments and policies. \\
\hline $\begin{array}{l}\checkmark \quad \text { Difference in these corruption perceptions } \\
\text { between the country of operation and the country of } \\
\text { domicile is also based on the CPI. }\end{array}$ & $\checkmark$ & Programs to uphold commitments and polices. \\
\hline $\begin{array}{l}\checkmark \quad \text { Political instability is based on World Bank's } \\
\text { 'World Governance Indicators'. }\end{array}$ & $\checkmark$ & Quality of community engagement \\
\hline $\begin{array}{l}\checkmark \quad \text { Government effectiveness is also based on World } \\
\text { Bank's 'World Governance Indicators'. }\end{array}$ & $\begin{array}{l}\checkmark \\
\text { abuse. }\end{array}$ \\
\hline
\end{tabular}


The oil and gas sector, as of yet, lacks transparency. Revenues don't get published and payments made to governments to exploit resources remain secret. Therefore the politicians and the industry insiders too often reap unlawful benefits. Most of the oil and gas organizations are wholly or partially state owned. Emerging markets tend to be bureaucratic which results in many 'touch points' with the government where bribes can be demanded. The oil and gas companies also protect the identities of their subsidiaries and equity holders, which makes it very easy for corrupt leaders to hide stolen funds. Without any published information and evidences of hidden royalties and taxes, it becomes very difficult to hold the government accountable.

About $85 \%$ of the world's proven oil reserves lie in the Middle East. The recent turmoil in the Middle East due to the gruesome civil wars and loss of lives has placed three countries from that region at the bottom of Transparency International's 2014 Corruption Perceptions Index (Kiany et al., 2015). The Institute for Analysis of Global security indicates that while only $9 \%$ of the world's oil is in the hands of countries ranked 'free' by the Freedom House, a whopping $22 \%$ of world's oil is unfortunately at the hands of state sponsors of terrorism. According to the 2002 Global Corruption Report of Transparency International, a major hindrance to the Middle East's economic development is corruption and lack of transparent government. The report also goes on to state that most of the GCC countries are plagued with nepotism, favoritism and profiteering (Institute for the Analysis of Global Security, 2015).

Areas without proper governance are prone to corruption. The gap between the rich and poor would increase, leading to poverty, chaos and terrorism. Decent and responsible governance providing the rule of the law, transparency and accountability is needed to spread economic well being across the land and overcome the dangers of power falling into the wrong hands.

\section{Findings}

There are many loopholes surrounding the concept of sustainability. Even though sustainable development has a short history, the issues surrounding the topic have been addressed till date in a multidimensional aspect. The concept of sustainable development was intended to provide the right framework for law makers, planners and decision makers so that issues concerning development, environmental safety and social responsibility could be addressed using an empirical methodology. However, the scope of sustainable development in the O\&G industry has been poorly defined, making it prone to ambiguity. Sustainability today, as addressed by the O\&G companies, majorly tends to take into concern only the management issue. Instead, it should actually question the involvement of the larger political dimension which has consequences on the operational methods of these companies. Today, the concept of sustainability is being interpreted in a multitude of different ways and sustainability cannot be achieved with conflicting notions of the concept at various levels.

\section{Summary and Discussion}

At the heart of the entire subject of sustainability are a few very important questions. Have we done enough to sustain the needs of the generations yet to come? How can we take sustainable development as a universal goal? How can we co-relate the three components (economic, environmental and social) of sustainable development?

The essence of sustainable development is scientifically and morally based problem solving. To achieve the economic, social and environmental objectives, a fourth objective must also be achieved: good governance. We must brainstorm our knowledge of the interconnections of the economy, society, environment and government. It is after all the governments which carry out functions for the prosperity of societies. In today's world, however, it is not just the governments to which the concept of 'good governance' falls back on. The world's multinational companies are often very important propelling forces.

Our well being depends on these powerful companies obeying the law and developing strategies for sustainable practices of their businesses in their operational environment (Dutta \& Sengupta, 2014). But corruption and malpractices bend the law to the favor of few. Therefore it is important for all the four pillars of the sustainable development to be concrete strong. We must work out our way through this century to produce prosperity which is inclusive, sustainable and that is with decent governance providing the rule of law displaying transparency and accountability.

With economic prosperity due to the O\&G industry, came in population growth. Fortunately, we have been able to reduce infant mortality rates and improvements are seen in the average life expectancy also. To make sure that the rising population is being provided with apt healthcare facilities and are also being kept above the poverty line, we need to make sure that this economic growth is inclusive, environmentally sustainable and is not leaving people behind. Economic well being must be shared alongside all ethnic, racial, religious and gender groups. 


\section{References}

Aridas, T., \& Pasquali, V. (2013). Countries with the GDP Average Growth, 2003-2013 | Global Finance Magazine. Retrieved from https://www.gfmag.com/global-data/economic-data/countries-highest-gdp-growth

Castagra.org. (2015). Top 7 Oil and Gas Disaster Videos. Retrieved from http://www.castagra.com/2013/10/top-7-oil-gas-disaster-videos/

Centre for Biological Diversity. (2015). Oil and Gas. Retrieved from http://www.biologicaldiversity.org/programs/public_lands/energy/dirty_energy_development/oil_and_gas/

DeMarrais, K. B., \& Lapan, S. D. (2004). Methods of Inquiry in Education and Social Sciences. Foundations of Research, 51(5/6), 546-545.

Dutta, A. B., \& Sengupta, I. (2014). Environmental Impact Assessment (EIA) and Construction. International Research Journal of Environmental Sciences, 3(1), 58-61.

Electricity from Oil. (2015). Retrieved from http://www.powerscorecard.org/tech_detail.cfm?resource_id=8

Environment Agency. (2013). An Environmental Risk Assessment for shale gas exploratory operations in England. Bristol: Environmental Agency. Retrieved from https://www.gov.uk/government/uploads/system/uploads/attachment_data/file/296949/LIT_8474_fbb1d4.p df

Farahani, A. F., Ahadmotlaghi, A., Farahani, A. F., \& Valafar, A. (2015). Pathology the Causes of Delay in the Major Project's of Oil Industrial, Case Study: South Pars. Journal of Recent Sciences, 4(3), 129-141.

Feeley, J., \& Brubaker, L. (2014). Anadarko tries to avoid liability for Macondo disaster. Business Day Live. Retrieved

from http://www.bdlive.co.za/world/americas/2014/03/26/anadarko-tries-to-avoid-liability-for-macondo-disaster

Health and Safety Executive. (2010). Offshore Injury and Incidents Statistics 2009/2010. Merseyside: Hazardous Installations Directorate Statistics Report HSR 2010 - 1.

Institute for the Analysis of Global Security. The Geopolitics of Oil. Retrieved from http://www.iags.org/geopolitics.html

Islam, M. R., \& Sumathy, K. (2013). Carbon Dioxide driven Solar-assisted Heat Pump Water Heating System: A Theoretical Analysis. International Research Journal of Environment Science, 2(10), 77-92.

Kiany, D., Rahimi, G., \& Jokar, M. S. (2015). Gas Exporting Companies forum, Past and Future. Research Journal of Recent Sciences, 4(5), 89-94.

Patton, M. Q. (2001). Qualitative Research and Evolution Methods (2nd ed.). Thousand Oaks, CA: Sage Publications.

Pawan, M. (2014). Impacts of Global Warming on Environment. International Research Journal of Environmental Sciences, 3(3), 72-78.

Prasad, S. J., Balakrishnan Nair, T. M., Francis, P. A., \& Vijayalaksmi, T. (2014). Hindcasting and Validating of Mumbai Oil Spills using GNOME. International Research Journal of Environmental Sciences, 3(12), $18-27$.

Shank, G. D. (2002). Qualitative Research: A Personal Skills Approach. Columbus, Ohio: Merrill Prentice Hall.

Sharma, R., Aggarwal, N., \& Kumar, S. (2014). Ecological Sustainability in India through the Ages. International Research Journal of Environmental Sciences, 3(1), 70-73.

Statista. (2015). Royal Dutch Shell, ExxonMobil and BP Revenues from 2001 to 2014 (in billion U.S. Dollars. Retrieved from http://www.statista.com/statistics/268734/revenue-of-royal-dutch-shell/

Steffy, L. (2010). New estimates on offshore drilling ban costs. Chron.com - Houston Chronicle. [Blog]. Retrieved from http://blog.chron.com//lorensteffy/2010/06/new-estimates-on-offshore-drilling-ban-costs/

Tollefson, J. (2013). Methane Leaks Erode Green Credentials of Natural Gas. Nature, 493(7430), 12.

UNSD (United Nations Sustainable Development). (1992). Agenda 21, United Nations Conference on Environment and Development. Rio De Janerio, Brazil, 3-14 June 1992. New York: United Nations.

US Energy Information Administration. (2015). Annual Energy Outlook 2015 with Projects to 2040. [Pdf]. Energy Information Administration. Retrieved from http://www.eia.gov/forecasts/aeo/ 


\section{Copyrights}

Copyright for this article is retained by the author(s), with first publication rights granted to the journal.

This is an open-access article distributed under the terms and conditions of the Creative Commons Attribution license (http://creativecommons.org/licenses/by/3.0/). 